\title{
Zespół Kounisa - interdyscyplinarny problem na styku alergologii i kardiologii
}

\section{Kounis syndrome - an interdisciplinary problem at the interface between allergology and cardiology}

\author{
Magdalena Feusette ${ }^{1}$, Katarzyna Kapeluszna', kukasz Moos', Piotr Feusette ${ }^{2}$, Jerzy Sacha ${ }^{3}$, \\ Marek Gierlotka², Zenon Brzoza' \\ ${ }^{1}$ Klinika Chorób Wewnętrznych, Instytut Nauk Medycznych, Uniwersytet Opolski \\ Kierownik Kliniki: dr hab. n. med. Zenon Brzoza, prof. Uniwersytetu Opolskiego \\ ${ }^{2}$ Klinika Kardiologii, Instytut Nauk Medycznych, Uniwersytet Opolski \\ Kierownik: prof. dr hab. n. med. Marek Gierlotka \\ ${ }^{3}$ Wydział Wychowania Fizycznego i Fizjoterapii, Politechnika Opolska \\ Dziekan Wydziału: dr hab. Dawid Bączkowicz, prof. Politechniki Opolskiej
}

\section{Streszczenie:}

Anafilaksja oznacza zagrażającą życiu, uogólnioną reakcję nadwrażliwości mogącą mieć charakter alergiczny lub niealergiczny. Zespół Kounisa to ostry zespół wieńcowy spowodowany reakcją alergiczną. Wśród czynników etiologicznych wyzwalających reakcję alergiczną wymienia się pokarmy, czynniki środowiskowe, leki, radiologiczne środki kontrastowe oraz niektóre stany chorobowe. Zespół Kounisa jest stosunkowo rzadko rozpoznawaną przyczyną zawału serca, co najprawdopodobniej wynika z jego niedorozpoznawalności. Przedstawiono przypadek pacjenta z wywiadem choroby niedokrwiennej serca, po zabiegach angioplastyki wieńcowej. Do momentu użądlenia przez owada przebieg dławicy miał charakter stabilny. Przebieg reakcji alergicznej miał charakter burzliwy i spełniał kryteria wstrząsu anafilaktycznego. Następnie u chorego pojawiły się niestabilne dolegliwości dławicowe. Na podstawie obrazu klinicznego i badań dodatkowych rozpoznano zawał serca. Koincydencja zawału z przebytym użądleniem przez owada pozwala uznać reakcję alergiczną za czynnik wyzwalający ostry zespół wieńcowy. Opisany przypadek zwraca uwagę na konieczność wielospecjalistycznego podejścia do pacjenta i regularny nadzór w czasie stosowania immunoterapii swoistej w przebiegu alergii na jad owadów błonkoskrzydłych, a także uwzględnianie zespołu Kounisa w diagnostyce różnicowej ostrych zespołów wieńcowych.

\begin{abstract}
:
Life-threatening anaphylaxis is a systemic hypersensitivity reaction that may be allergic or non-allergic. Kounis syndrome is an acute coronary syndrome caused by an allergic reaction. Food, environmental factors, drugs, radiological contrast agents and some disease states are among the etiological factors that trigger an allergic reaction. Kounis syndrome is a relatively rarely recognized cause of myocardial infarction, which is most likely due to its underdiagnosis. The presented case concerns a patient with a history of ischemic heart disease after coronary angioplasty. Until the insect stings, the course of the angina was stable. The course of the allergic reaction was turbulent and met the criteria for anaphylactic shock. Subsequently, the patient developed unstable angina. The clinical picture and additional tests allowed to diagnose a myocardial infarction in the patient. The coincidence of myocardial infarction with a history of an insect sting allows for the recognition of an allergic reaction as a trigger for acute coronary syndrome. The described case highlights the need for a multidisciplinary approach to the patient and regular supervision during the use of specific immunotherapy in the course of allergy to Hymenoptera venom, as well as the inclusion of Kounis syndrome in the differential diagnosis of acute coronary syndromes.
\end{abstract}

Słowa kluczowe: anafilaksja, ostry zespół wieńcowy, zespół Kounisa

Key words: anaphylaxis, acute coronary syndrome, Kounis syndrome 


\section{Wstęp}

Anafilaksja oznacza ciężką, zagrażającą życiu, uogólnioną reakcję nadwrażliwości mogącą mieć charakter alergiczny lub niealergiczny. Jest najczęściej inicjowana przez zależną od $\operatorname{IgE}$ (immunoglobuliny E) degranulację komórek tucznych (mastocytów) i bazofilów w wyniku kontaktu $\mathrm{z}$ antygenem. W fazie późnej uczestniczą dodatkowo m.in. eozynofile, neutrofile i płytki krwi. Wiążąc się z IgE, alergen na powierzchni mastocytu powoduje mostkowanie receptorów FcєRI (receptor o wysokim powinowactwie dla $\operatorname{IgE})$, stymulując uwolnienie przez komórkę tuczną mediatorów. Mianem wstrząsu anafilaktycznego określamy szybko rozwijającą się reakcję anafilaktyczną, w której przebiegu dochodzi do zagrażającego życiu spadku ciśnienia tętniczego krwi [1].

Wyróżnia się trzy typy mediatorów reakcji alergicznej:

- obecne w ziarnistościach mediatory preformowane, takie jak: histamina, heparyna, tryptaza i chymaza, oraz czynniki chemotaktyczne: anafilaktyczny czynnik chemotaksji eozynofilów (ECF-A, eosinophil chemotactic factor of anaphylaxis) $\mathrm{i}$ anafilaktyczny czynnik chemotaksji neutrofilów (NCF-A, neutrophil chemotactic factor of anaphylaxis)

- cytokiny - czynnik martwicy nowotworów (TNF- $\alpha$, tumor necrosis factor) i interleukina 4 (IL-4) - oraz chemokiny uwalniające się po kilku godzinach od zadziałania bodźca

- mediatory syntezowane de novo po stymulacji, takie jak: leukotrieny, tromboksany, czynnik aktywujący płytki (PAF, platelet-activating factor), adenozyna, rodniki nadtlenkowe, prostaglandyny $\mathrm{PGD}_{2}$ oraz leukotrieny cysteinylowe typu 4 (LTC4).

Mastocyty zostały odkryte i opisane po raz pierwszy przez Paula Ehrlicha w 1876 r. Komórki te są produkowane w szpiku kostnym i uwalniane do krą- żenia jako komórki prekursorowe. Ponieważ komórki macierzyste wykazują ekspresję receptorów c-KIT (receptor kinazy tyrozynowej), pod wpływem czynników wzrostu namnażają się, różnicując w kierunku dojrzałych mastocytów.

Mastocyty zasiedlają różne tkanki, w tym tkankę nerwową w mózgu, gdzie w prawidłowych warunkach z uwagi na nieprzepuszczalność dla przeciwciał bariery krew-mózg nie występują reakcje alergiczne. Komórki tuczne zwykle lokalizują się w okolicy drobnych naczyń krwionośnych w narządach stykających się ze środowiskiem zewnętrznym (błony śluzowe), w tkance łącznej (otrzewna) lub wokół nerwów. W ich cytoplazmie znajdują się liczne, ciemne, zasadochłonne ziarna, mające właściwość metachromazji. Ziarnistości mastocytów są szczególnie bogate w histaminę i heparynę. Ich pobudzenie prowadzi do wydzielania znacznej ilości prostaglandyn i cytokin (np. Il-4, TNF- $\alpha$, PAF). Zawierają również proteazy (np. tryptazę lub chymazę). PAF jest czynnikiem aktywującym agregację płytek krwi oraz ich degranulację, inicjuje kaskadę krzepnięcia, co prowadzi do zjawisk zakrzepowych.

Za zawał serca w przebiegu zespołu Kounisa odpowiada degranulacja mastocytów. Stymulacja receptorowa nie tylko wywołuje wazokonstrykcję, lecz także sprzyja pękaniu blaszek miażdżycowych, co powoduje niedokrwienie mięśnia sercowego. Zespół Kounisa może wstąpić nie tylko po ekspozycji na jad owadów błonkoskrzydłych - opisywane w literaturze przypadki dotyczyły chorych ukąszonych przez kobrę, żmiję, po przyjęciu kwasu acetylosalicylowego, a także po zastosowaniu radiologicznych środków kontrastowych [2-6] (ryc. 1). Stymulacja receptorów histaminowych typu $1\left(\mathrm{H}_{1}\right)$ powoduje wazokonstrykcję naczyń wieńcowych (co było wykorzystywane $\mathrm{w}$ teście histaminowym), a ponadto zwiększa przepuszczalność naczyń. Stymulacja receptorów histaminowych typu $2\left(\mathrm{H}_{2}\right)$ przyspiesza akcję serca,

Rycina 1. Etapy reakcji anafilaktycznej prowadzącej do objawów zespołu Kounisa.

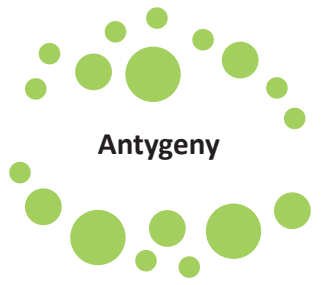

- leki

- pokarmy

- jady owadów

- środki kontrastowe

- obciążenia chorobowe

- ekspozycja

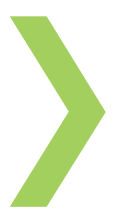

Aktywacja

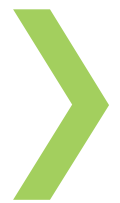

Mediatory zapalne

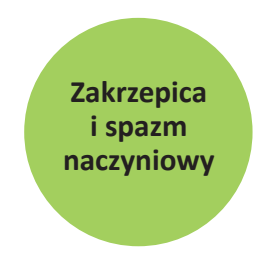

- mastocytów

- limfocytów
- histamina

- chemokiny

- tryptaza, chymaza

- leukotrieny 
co stanowi przyczynę niewielkiej relaksacji naczyń wieńcowych i zwiększenia kurczliwości mięśnia sercowego. Dodatkowo histamina poprzez receptor $\mathrm{H}_{1}$ $\mathrm{w}$ trakcie reakcji anafilaktycznej stymuluje wytwarzanie tlenku azotu z L-argininy, co powoduje obniżenie ciśnienia tętniczego krwi.

\section{Opis przypadku}

59-letni chory regularnie stosujący leki, po zawale serca ściany dolnej i angioplastyce gałęzi marginalnej (OM, obtuse marginal) z implantacją stentów metalowych (BMS, bare metal stents) w 2011 r.; po powtórnym zawale serca i angioplastyce prawej tętnicy wieńcowej oraz implantacji stentów uwalniających lek (DES, drug-eluting stents) w 2013 r., z nadciśnieniem tętniczym, nikotynizmem, po przebytym zakrzepowym zapaleniu żyły odłokciowej lewej, został przyjęty na Oddział Kardiologii Uniwersyteckiego Szpitala Klinicznego w Opolu z objawami zawału serca bez uniesienia odcinka ST. W dniu przyjęcia pacjent został użądlony przez owada błonkoskrzydłego, prawdopodobnie osę. Przy przyjęciu demonstrował duszność, pokrzywkę, spadek ciśnienia tętniczego krwi. Dodatkowo w trakcie pobytu na SOR dołączyły się dolegliwości stenokardialne. W zapisach elektrokardiografii (EKG) obserwowano deniwelację odcinka ST 0,5-1 mm w odprowadzeniach $\mathrm{V}_{3}-\mathrm{V}_{5}$. W badaniach laboratoryjnych zanotowano podwyższone parametry kardionekrozy z dynamiką typową dla zawału mięśnia sercowego. W ocenie echokardiograficznej obserwowano odcinkowe zaburzenia kurczliwości mięśnia sercowego w zakresie lewej komory z obniżoną jej frakcją wyrzutową (EF, ejection fraction) do 45\%, małą niedomykalność zastawki mitralnej przy niewielkim prawdopodobieństwie nadciśnienia płucnego. W koronarografii uwidoczniono rozsiane zmiany w tętnicach nasierdziowych $\mathrm{z}$ amputowaną gałęzią OM oraz restenozę w stencie. Wykonano zabieg angioplastyki balonowej i angioplastyki gałęzi okalającej (Cx, circumflex artery) z implantacją DES (pod kontrolą ultrasonografii wewnątrznaczyniowej [IVUS, intravascular ultrasound]). W teście wysiłkowym odnotowano dobrą rezerwę wieńcową, bez dolegliwości dławicowych przy 10,2 METs (jednostka spoczynkowego poboru tlenu). W badaniu EKG metodą Holtera stwierdzono wiodący rytm zatokowy, pojedyncze pobudzenia komorowe, bez groźnych arytmii. Pacjenta zakwalifikowano do dalszego leczenia zachowawczego choroby wieńcowej. Wypisano go z oddziału kardiologii w stanie ogólnym dobrym, a następnie w trybie planowym przyjęto na oddział chorób wewnętrznych i alergologii w celu kwalifikacji i ewentualnego wdrożenia immunoterapii jadem owadów błonkoskrzydłych (VIT, venom immunotherapy). W trakcie hospitalizacji przeprowadzono badania laboratoryjne oraz obrazowe. Ze względu na stwierdzone w badaniach laboratoryjnych podwyższone wartości glikemii na czczo wykonano test doustnego obciążenia glukozą, który wykazał nieprawidłową tolerancję glikemii. Ponadto w ultrasonografii (USG) jamy brzusznej zobrazowano poszerzenie aorty brzusznej do $40 \mathrm{~mm}$; konsultujący chirurg naczyniowy zalecił okresową kontrolę ambulatoryjną. W przeszłości u pacjenta po użądleniu przez osę lub pszczołę występowały tylko reakcje miejscowe. Wykonane testy śródskórne wykazały wynik dodatni z jadem osy, a ujemny - z jadem pszczoły. Stężenie tryptazy mieściło się $\mathrm{w}$ granicach normy. Wykazano obecność przeciwciał IgE-swoistych wobec jadu osy (miano: klasa druga). Badania komponent alergenowych wykazały klasę czwartą miana dla antygenu 5 RVes v5 jadu osy. Ponadto stwierdzono klasę pierwszą miana IgE wobec alergenu jadu pszczoły oraz klasę pierwszą wobec komponent alergenowych dla jadu pszczoły - RApi m2-hialuronidazy, RApi m10-ikarapiny. Dla jadu pszczoły wykazano tym samym uczulenie bezobjawowe klinicznie. W oparciu o całość obrazu oraz na podstawie przeprowadzonej diagnostyki stwierdzono IgE-zależny charakter reakcji poużądleniowej - chorego zakwalifikowano do immunoterapii jadem osy. Pacjent spełnił zarówno kryterium kliniczne, jak i immunologiczne wdrożenia immunoterapii jadem osy. Ze względu na obraz kliniczny reakcji poużądleniowej oraz choroby współistniejące rozpoczęto szczepienie jadem osy według schematu cluster. W ciągu kolejnych tygodni osiągnięto zaplanowaną dawkę $100 \mu \mathrm{g}$ jadu osy, po czym nie obserwowano powikłań. W trakcie leczenia pacjent nie był ponownie żądlony przez owady polne.

\section{Dyskusja}

Zespół Kounisa to ostry zespół wieńcowy spowodowany reakcją alergiczną. Wśród mediatorów zapalnych biorących udział $\mathrm{w}$ patomechanizmie tego zespołu wymienia się histaminę, pochodne kwasu arachidonowego, proteazę neutralną, czynnik aktywacji płytek, chemokiny i cytokiny. Do czynników etiologicznych wyzwalających reakcję alergiczną należą: pokarmy (m.in. skorupiaki), czynniki środowiskowe (alergeny jadu owadów błonkoskrzydłych), leki (m.in. penicylinę), radiologiczne środki kontrastowe oraz niektóre stany chorobowe (np. mastocytoza, anisakioza). Zespół Kounisa jest stosunkowo rzadko rozpozna- 
waną przyczyną zawału serca, co wynika najprawdopodobniej z jego niedorozpoznawalności. Znacznie częściej przyczyny spazmu naczyń wieńcowych mają charakter niealergiczny, np. dławica Prinzmetala, eozynofilowe zapalenie tętnic wieńcowych.

$\mathrm{Z}$ uwagi na mechanizm prowadzący do niedokrwienia mięśnia sercowego w zespole Kounisa wyróżnia się następujące typy:

- typ 1 - związany ze spazmem naczyniowym u pacjentów bez dotychczas rozpoznanej choroby niedokrwiennej serca z prawidłowym obrazem naczyń wieńcowych w koronarografii, bez klasycznych czynników ryzyka miażdżycy

- typ 2 - u pacjentów bez jawnej klinicznie choroby niedokrwiennej serca, z obecnością zmian miażdżycowych; uwolnienie mediatorów zapalnych może wywołać spazm naczyniowy bez pęknięcia blaszki miażdżycowej lub z pęknięciem

- typ 3 - związany z wystąpieniem zakrzepicy w naczyniu wieńcowym, w tym u chorych po implantacji stentu, w efekcie reakcji alergicznej. W badanym wówczas materiale zakrzepowym stwierdzano obecność eozynofili i miocytów. Do tego typu zalicza się również pacjentów, u których doszło do nagłego zgonu po implantacji stentu z udowodnioną reakcją alergiczną odnotowaną w badaniu pośmiertnym. Wyróżnia się dwa podtypy w tym obszarze:

- zakrzepica w stencie

- restenoza w stencie [7-10] (ryc. 2).

Przedstawiony opis przypadku dotyczy pacjenta z wywiadem choroby niedokrwiennej serca i po zabiegach angioplastyki wieńcowej z implantacją stentów.
Do momentu użądlenia przez owada przebieg dławicy miał charakter stabilny ze sporadycznie występującymi dolegliwościami dławicowymi - klasa pierwsza według Kanadyjskiego Towarzystwa Kardiologicznego (CCS, Canadian Cardiovascular Society). Przebieg reakcji alergicznej miał charakter burzliwy i spełniał kryteria wstrząsu anafilaktycznego (pokrzywka, duszność, spadek ciśnienia tętniczego krwi). Następnie u chorego pojawiły się dolegliwości dławicowe, spełniające kryteria niestabilności. $\mathrm{Na}$ podstawie obrazu badania EKG, echokardiograficznego oraz dynamiki markerów uszkodzenia mięśnia sercowego rozpoznano zawał serca. Wykonana koronarografia wykazała amputację tętnicy wieńcowej w miejscu uprzednio implantowanego stentu w gałęzi OM. Badanie IVUS wykazało obecność skrzepliny i pękniętej blaszki miażdżycowej, co wymagało kolejnego zabiegu angioplastyki. Koincydencja zawału z przebytym użądleniem przez owada pozwala uznać reakcję alergiczną za czynnik wyzwalający ostry zespół wieńcowy. Zaistniały incydent można zakwalifikować jako zespół Kounisa typu 3 przebiegający z zakrzepicą w uprzednio implantowanym stencie. Możliwym czynnikiem, który dodatkowo przyczynił się do wytworzenia zakrzepicy, była hipotonia towarzysząca reakcji anafilaktycznej.

\section{Podsumowanie}

Opisany przypadek zwraca uwagę na konieczność wielospecjalistycznego podejścia do chorego i regularnego nadzoru w czasie stosowania VIT, a także uwzględniania zespołu Kounisa w diagnostyce różnicowej ostrych zespołów wieńcowych.

Rycina 2. Typy zespołu Kounisa.

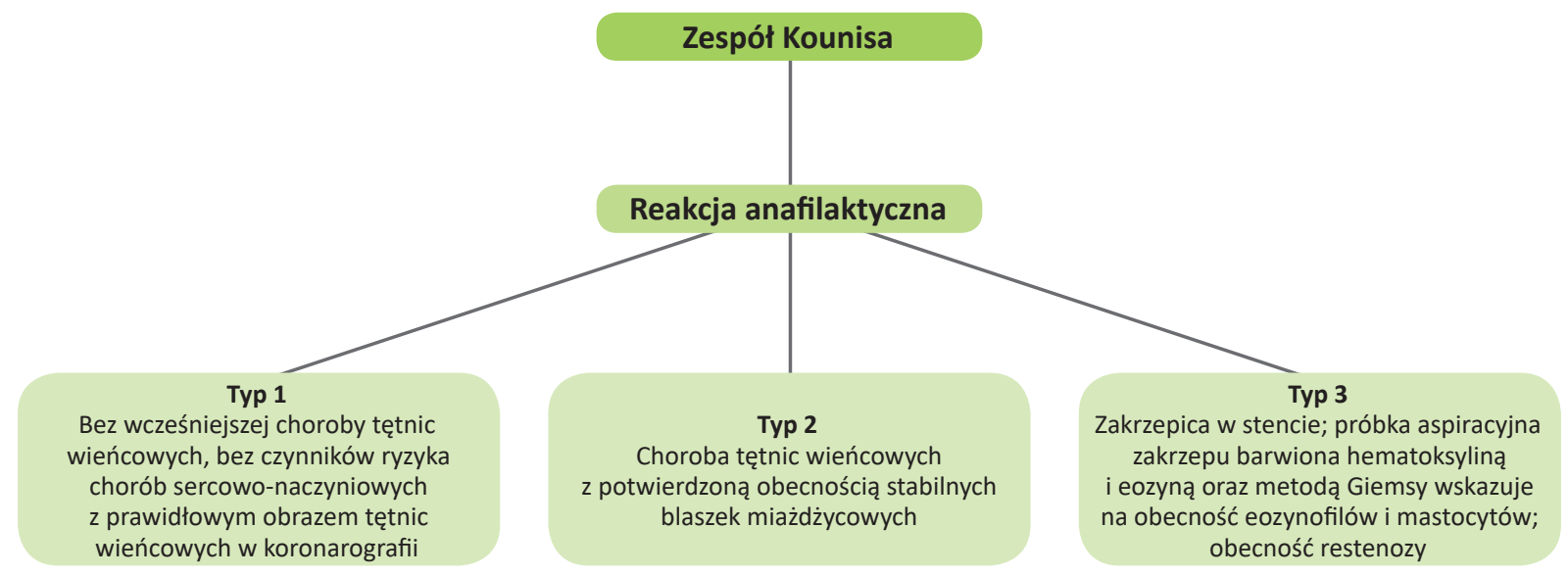




\section{Piśmiennictwo}

1. Muraro A, Roberts G, Worm M et al. Anaphylaxis: guidelines from the European Academy of Allergy and Clinical Immunology. Allergy. 2014; 69: 1026-45.

2. Kounis NG, Koniari I, Velissaris D et al. Kounis Syndromenot a Single-organ Arterial Disorder but a Multisystem and Multidisciplinary Disease. Balkan Med J. 2019; 36: 212-21.

3. Priyankara WDD, Manoj ED, Gunapala A et al. Cardiogenic shock due to Kounis Syndrome following Cobra Bite. Case Rep Crit Care. 2019; 2019: 5185716.

4. Hangouche AJE, Lamliki O, Oukerraj L et al. Kounis syndrome induced by oral intake of aspirin: a case report and literature review. Pan Afr Med J. 2018; 30: 301.

5. Bhaskaran A, Deshmukh T, Sivagangabalan G. Intraprocedure Type II Kounis Syndrome Secondary to Radioiodine Contrast During Coronary Angiography. Can J Cardiol. 2018; 34: 1688.e1-1688.e3.

6. Böhm I. Kounis syndrome in a patient with allergy to iodinated contrast media. Int J Cardiol. 2011; 151: 102-3.

7. Sueda S, Sasaki Y, Habara H et al. Editorial: Kounis syndrome (allergic angina and allergic myocardial infarction) for cardiologists. J Cardiol Cases. 2015; 12: 110-2.

8. Kounis NG. Kounis syndrome: an update on epidemiology, pathogenesis, diagnosis and therapeutic management. Clin Chem Lab Med. 2016; 54: 1545-59.

9. Chen JP, Hou D, Pendyala L et al. Drug-eluting stent thrombosis the Kounis hypersensitivity-associated acute coronary syndrome revisited. JACC Cardiovasc Interv. 2009; 2: 583-93 .
10. Hoshi T, Sato A, Akiyama D et al. Kounis Syndrome Manifesting as Coronary Aneurysm and Very Late Coronary Stent Thrombosis. JACC Cardiovasc Interv. 2014; 7: 173-6.

ORCID

M. Feusette - ID - http://orcid.org/0000-0002-6830-1710

K. Kapeluszna - ID - http://orcid.org/0000-0003-0050-0139

Ł. Moos - ID - http:///orcid.org/0000-0002-7906-0035

P. Feusette - ID - http://orcid.org/0000-0002-5436-987X

J. Sacha - ID - http://orcid.org/0000-0001-7504-7506

M. Gierlotka - ID - http://orcid.org/0000-0001-5639-2128

Z. Brzoza - ID - http://orcid.org/0000-0002-1230-7013

Wkład autorów/Authors' contributions:

M. Feusette: analiza piśmiennictwa, przygotowanie manuskryptu, opracowanie rycin; K. Kapeluszna: analiza piśmiennictwa, przygotowanie manuskryptu; Ł. Moos: analiza piśmiennictwa, przygotowanie manuskryptu; P. Feusette: analiza piśmiennictwa, przygotowanie manuskryptu, opracowanie rycin; J. Sacha: korekta manuskryptu; M. Gierlotka: korekta manuskryptu; Z. Brzoza: przygotowanie i korekta manuskryptu. Konflikt interesów/Conflict of interests:

Nie wystepuje.

Finansowanie/Financial support:

Nie wysteppuje.

Etyka/Ethics:

Treści przedstawione w artykule są zgodne z zasadami Deklaracji Helsińskiej, dyrektywami EU oraz ujednoliconymi wymaganiami dla czasopism biomedycznych.

Copyright: ( ) Medical Education sp. z 0.0. This is an Open Access article distributed under the terms of the Attribution-NonCommercial 4.0 International (CC BY-NC 4.0). License (https://creativecommons.org/licenses/by-nc/4.0/), allowing third parties to copy and redistribute the material in any medium or format and to remix, transform, and build upon the material, provided the original work is properly cited and states its license.

Adres do korespondencji

\section{lek. Magdalena Feusette}

Klinika Chorób Wewnętrznych, Uniwersytecki Szpital Kliniczny w Opolu 45-401 Opole, al. W. Witosa 26 e-mail: magdalena.bemben@uni.opole.pl 